\title{
GENETICS AND PLASTID PHYSIOLOGY IN PELARGONIUM
}

\section{EFFECT OF CULTIVAR AND PLASTIDS ON FERTILISATION AND EMBRYO SURVIVAL}

\author{
R. A. E. TILNEY-BASSETT \\ Department of Genetics, University College of Swansea
}

Received 20.iii.69

\section{THE SELEGTION HYPOTHESIS}

Normal and mutant plastids are contributed by both parents in Pelargonium zonale as was first shown in the outstanding classical experiments of Baur (1909). These experiments have been repeated by several workers (see Tilney-Bassett, 1963b; Hagemann, 1964) and the results confirmed. On selfing, white margined cultivars, containing mutant white plastids in the germ layers, give white offspring, green cultivars give green offspring and reciprocal crosses between the two give various ratios of green, variegated and white offspring. Reciprocal crosses do not generally give reciprocal proportions of offspring, instead the majority of embryos and seedlings are usually green whichever way the cross is made.

The predominance of green seedlings has been observed by all workers but not explained. As a working hypothesis, I suggested (1963b) that white embryos and to a less extent variegated embryos might be strongly selected against during development so that few of these reached maturity; germination would be mostly of green ones. Examination of mature seeds showed that they were of two kinds, plump seeds which germinated and dwarf, shrivelled seeds which failed to germinate. Furthermore, the proportion of shrivelled seeds was high enough to account completely for the deficit of expected white seedlings in the $\mathrm{W} \times \mathrm{G}$ crosses, assuming that the shrivelled were in fact the supposed white ones deficient in the segregating ratios. If the hypothesis proved true then it would be seen that reciprocal crosses did, after all, give reciprocal results in which the maternal parent made the greater contribution of plastids to the phenotype of the young embryos prior to selection. The plastid inheritance would thus be essentially the same as found in Oenothera species, in which normal and defective plastids are also transmitted by both parents but predominantly by the female (see Kirk and Tilney-Bassett, 1967; Schötz, 1954, 1958, 1968).

To test the hypothesis it was necessary to know whether the shrivelled, non-germinating seeds really were potentially white. This test proved possible (Tilney-Bassett, 1965) because in Pelargonium the embryo is large and fully developed before the seed matures. The embryos are covered by a transparent testa that allows the development of normal plastids to green chloroplasts, while abnormal mutants plastids do not develop into chloroplasts, they remain white. Hence, depending on the plastid constitution, the young embryos are seen to be green, variegated or white. When these young embryos are scored, after dissecting them from their seeds, it is found that healthy embryos are distinguishable from dead and dying ones and in each case the proportions of green, variegated and white are countable. The segregation ratios observed are not markedly different from those found 
after germination demonstrating that the hypothesis of strong selection against white embryos during development is not tenable (Tilney-Bassett, 1965; Kirk and Tilney-Bassett, 1967). This does not rule out the possibility of selection occurring at a very early stage when dead embryos would be too small to score with the stereomicroscope. If large numbers of potentially white embryos do die during very early stages of embryo development, after $\mathrm{W} \times \mathrm{G}$ crosses, then their absence from scoring would be detectable by a corresponding depression of the calculated mean fertilisation values, as compared with $\mathrm{G} \times \mathrm{G}$ and $\mathrm{G} \times \mathrm{W}$ crosses. Also it might be expected that the mean fertilisation values of $\mathrm{W} \times \mathrm{W}$ crosses would be depressed by at least as much. Limited comparisons within cultivars Dolly Varden and Flower of Spring have so far suggested that there is no depression of the fertilisation values, and hence no early selective elimination of white embryos on a large scale.

In the present paper within cultivar fertilisation and embryo survival values are based on more numerous observations and placed on a statistical footing. In addition, data are given following all the eight possible combinations of crosses between the two cultivars. By analysis of variance the effects of the cultivars are distinguished from the effects of the plastids firstly, on mean fertilisation values and secondly, on the mean frequencies of good viable embryos at the end of their growth phase approximately three weeks after pollination. In a separate experiment survival of seeds to maturity and their subsequent germination is analysed for the mixed plastid pollinations.

\section{Materials AND MEthods}

As source of mutant white plastids (W), the cultivars used in the breeding programme are Dolly Varden (DV) and Flower of Spring (FS) and, as source of green plastids $(G)$, the isogenic green clones derived from them; their description and the methods of their cultivation and breeding have been given in earlier reports (Tilney-Bassett, 1963b, 1965). Pollinations within cultivars are nuclear selfs and between cultivars nuclear crosses. Yet, in regard to the plastids, nuclear selfs may be plastid crosses, FS G $\times$ W FS and FS W $\times$ G FS for example, or nuclear crosses may be, at least phenotypically, plastid selfs, DV G $\times$ G FS and FS W $\times$ W DV for example. To avoid confusion, the terms " selfs" and "crosses" used alone are restricted to pollinations within and between cultivars irrespective of the plastid constitution. When preceded by "plastid" the same terms refer to the plastid parentage irrespective of that of the cultivars.

Each flower contains five carpels, within each of which two ovules are produced. Yet it is extremely rare for all ten ovules to be functional, and on an average less than one from each carpel is fertilised to give approximately three embryos per flower. Often no embryos are produced, and the normal elongation of the style following pollination does not take place. Clearly there has been no fertilisation; the reasons probably include an absence of functional ovules, old pollen, non-receptive stigmas, damaged stigmas or flower pedicels, fungal and bacterial infection and perhaps other causes as well. Unfortunately the frequency of such flowers is so variable that they completely distort fertility estimates. To overcome this problem, all scorings are based on flowers producing at least one developing embryo, good or bad, and flowers failing to produce any embryos are discarded. 
Ten days after pollination the young straight embryo is less than $0.5 \mathrm{~cm}$. long with the cotyledonary bulges just visible; by three weeks the folded embryo is as much as $2 \mathrm{~cm}$. long with the cotyledons fully expanded. Embryos which fully expand their cotyledons include all those that subsequently germinate and they are scored as good, full embryos. A portion of embryos fail to expand their cotyledons and remain small and sometimes extremely dwarf; at least by three weeks, and often before two weeks, these bad embryos are easily distinguishable from good ones through exhibiting clear symptoms of dying. Because of their smallness and the lack of expanded cotyledons, it is probable that a few bad embryos are misclassified as green or white when they are really variegated; the effect on segregating ratios can only be slight and fertilisation data are unaffected. Occasionally seeds are found which outwardly appear of normal size for two to three weeks old, yet when cut open, instead of containing an embryo, are found to be full of a watery liquid. Although such empty (E) seeds cannot be classified, it is assumed that they have been fertilised, otherwise such considerable growth would presumably not have taken place; probably there has been growth of the endosperm without growth of the embryo.

Some embryos from $\mathrm{G} \times \mathrm{W}$ and $\mathrm{W} \times \mathrm{G}$ plastid crosses are completely white except for dark green tips, filled with chloroplasts, at the suspensor end of the embryo. These are scored as white, and not variegated, because white is how they would appear had they been germinated, there being no green spots in the hypocotyl or cotyledons. When scored, variegated embryos are classified into ten groups according to their relative proportions of green and white tissues. For simplicity, they are simply recorded as variegated in the present paper since the degree of variegation has no bearing on fertilisation and little or none on viability data. Moreover, comparisons of segregating ratios within the same cross, after scoring at different stages of development, are not seriously affected by grouping all variegateds together.

\section{EMBRYo AND SEEDLING SEGREGATION}

In order to produce sufficient numbers of embryos for useful analysis it was necessary to pollinate almost daily from May till October. As a check on seasonal variations some crosses were repeated in different months, but $\chi^{2}$ analysis showed no significant differences between the segregating ratios tested and their data are combined. At the beginning of the flowering season, in early April, fertilisation values tended to be rather low and so data for this month have not been included.

The segregation of total and good embryos for the sixteen combinations of selfs and crosses within and between the cultivars F. of Spring and D. Varden is shown in table 1, along with the segregation of seedlings for the mixed plastid crosses. The scoring of total and good embryos is based on the same flowers so that the data for good embryos is derived from the total embryos minus the dying embryos, recognised three weeks after pollination. The seedling data is derived from a separate series of crosses, pollinated in late October to early November for the most part, and the seeds germinated in December.

As expected $G \times G$ plastid selfs gave green offspring, $G \times W$ and $W \times G$ plastid crosses gave varying ratios of green, variegated and white offspring, and $\mathrm{W} \times \mathrm{W}$ plastid selfs gave white offspring. At least, the $\mathrm{F}$. of Spring 
selfed white gave all white offspring, but selfs or crosses utilising the white plastids of D. Varden produced a small proportion of variegated offspring containing isolated green flecks or sectors on a white background. The occurrence of these green flecks is typical of D. Varden; presumably the mutant white plsatids sporadically revert or back-mutate to green. The varying frequency of flecking observed between the three $W \times W$ selfs or crosses is not significant $\left(\chi^{2}=4 \cdot 452, \mathrm{P}=0 \cdot 2-0 \cdot 1\right)$. In many cases the green flecks were in the radicle and would not therefore have been discovered in a

TABLE 1

Segregation of total and good embryos for the sixteen combinations of selfs and crosses within and between the cultivars Flower of Spring and Dolly Varden, and segregation of seedlings for the mixed plastid crosses

\begin{tabular}{|c|c|c|c|c|c|c|c|c|c|c|c|c|c|}
\hline \multirow[b]{2}{*}{ Selfs and crosses } & \multicolumn{5}{|c|}{ Total embryos } & \multicolumn{4}{|c|}{ Good embryos } & \multicolumn{4}{|c|}{ Seedlings } \\
\hline & G & $\mathrm{V}$ & $\mathrm{W}$ & $\mathbf{E}$ & Total & G & V & W & Total & $\mathrm{G}$ & $\mathrm{V}$ & W & Total \\
\hline $\mathrm{FS} \quad \mathrm{G} \times \mathrm{G} F \mathrm{~F}$ & 250 & - & - & 5 & 255 & 227 & - & - & 227 & 一 & - & - & - \\
\hline FS $\mathrm{G} \times \mathrm{G}$ DV & 676 & - & - & 14 & 690 & 585 & 一 & - & 585 & 一 & - & 一 & 一 \\
\hline $\mathrm{DV} \mathrm{G} \times \mathrm{G} F \mathrm{~S}$ & 476 & - & 一 & 3 & 479 & 451 & 一 & - & 451 & - & - & - & - \\
\hline $\mathrm{DV} \mathrm{G} \times \mathrm{G} \mathrm{DV}$ & 283 & - & - & 20 & 303 & 256 & 一 & - & 256 & 一 & - & - & 一 \\
\hline FS $\quad G \times W F S$ & 365 & 40 & 358 & 12 & $\mathbf{7 7 5}$ & 334 & 39 & 292 & 665 & 104 & 14 & 73 & 191 \\
\hline $\mathrm{FS} \quad \mathrm{G} \times \mathrm{WDV}$ & 236 & 115 & 224 & 2 & 577 & 220 & 111 & 210 & 541 & 47 & 26 & 78 & 151 \\
\hline DV $\mathrm{G} \times W \mathrm{FS}$ & 412 & 110 & 59 & 6 & 587 & 381 & 106 & 40 & 527 & 380 & 75 & 7 & 462 \\
\hline $\mathrm{DV} \mathrm{G} \times \mathrm{W} \mathrm{DV}$ & 259 & 123 & 81 & 12 & 475 & 227 & 122 & 67 & 416 & 153 & 71 & 11 & 235 \\
\hline $\mathrm{FS} \quad \mathrm{W} \times \mathrm{G} F \mathrm{FS}$ & 283 & 94 & 19 & 10 & 406 & 256 & 91 & 14 & 361 & 115 & 27 & 2 & 144 \\
\hline $\mathrm{FS} \quad \mathrm{W} \times \mathrm{G} D \mathrm{DV}$ & 337 & 74 & 11 & 5 & 427 & 315 & 73 & 4 & 392 & 129 & 44 & 2 & 175 \\
\hline DV $W \times G \quad F S$ & 394 & 197 & 71 & 23 & 685 & 308 & 188 & 53 & 549 & 129 & 89 & 39 & 257 \\
\hline $\mathrm{DV} W \times \mathrm{G} D \mathrm{DV}$ & 237 & 155 & 35 & 5 & 432 & 174 & 144 & 25 & 343 & 84 & 63 & 14 & 161 \\
\hline $\mathrm{FS} \quad \mathrm{W} \times \mathrm{W} \mathbf{F S}$ & - & - & 260 & 15 & 275 & - & - & 168 & 168 & - & 一 & - & - \\
\hline $\mathrm{FS} \quad \mathrm{W} \times \mathrm{WDV}$ & - & 37 & 192 & 11 & 240 & - & 36 & 143 & 179 & 一 & - & - & - \\
\hline DV $W \times W F S$ & - & 20 & 377 & 22 & 419 & - & 20 & 227 & 247 & - & - & - & 一 \\
\hline$\overline{D V} \mathrm{~W} \times \mathrm{W} \mathrm{DV}$ & 1 & 25 & 266 & 43 & 335 & - & 20 & 125 & 145 & - & - & - & - \\
\hline
\end{tabular}

germinating seedling. Furthermore, the green areas were often solitary per embryo and so small that they would surely have been overlooked by the naked eye, although clearly visible under the stereoscopic microscope. The single pure green dwarf embryo may have arisen through a layer alteration; D. Varden is a three layered mesochimera with the structure GWG (TilneyBassett, 1963a).

In this paper, I do not wish to make a detailed analysis of the varying segregation ratios following mixed plastid crosses. I wish to concentrate instead on an examination of the changes in these ratios for total fertilisation, for good embryos three weeks after pollination, and for seedlings approximately six weeks after pollination. The seeds mature in four weeks or just over and take at least a week to germinate; they germinate best if sown immediately after ripening.

The segregation ratios from table 1 are compared by the contingency $\chi^{2}$ test and the results of the analysis shown in table 2. In addition, the class of good embryos or seedlings which are below expectation are indicated in the deficit columns. The first deficit column is interesting because it shows that, compared with total embryos, there were always fewer white and often fewer green good embryos than expected. In other words, there was always an 
excess of variegated good embryos and hence a corresponding deficiency of variegated total embryos, the good and the bad together. This is undoubtedly indicative of a failure to score the dead or dying embryos as accurately as the larger healthy ones. A few of the apparently white or green embryos must have been variegated with a small spot of green or white respectively that, probably owing to the discoloration accompanying embryo death, passed unnoticed. This interpretation is also supported by the observation, apparent from the data of table 1, that conspicuously fewer variegated embryos were classified as bad as compared with green and white.

TABLE 2

Comparison of segregating ratios from table 1 by contingency $\chi^{2}$ test between total fertilised and good embryos, and between good embryos and seedlings

\begin{tabular}{|c|c|c|c|c|c|c|c|}
\hline \multirow{2}{*}{\multicolumn{2}{|c|}{ Cross }} & \multicolumn{3}{|c|}{ Total fertilised: good embryos } & \multicolumn{3}{|c|}{ Good embryos : Seedlings } \\
\hline & & $x^{2}$ & $\mathbf{P}$ & Deficit & $\chi^{2}$ & $\mathrm{P}$ & Deficit \\
\hline FS & $\mathrm{G} \times \mathrm{W}$ FS & $1 \cdot 370$ & $0.70-0.50$ & W & $2 \cdot 166$ & $0.50-0.30$ & $\mathrm{w}$ \\
\hline FS & $\mathrm{G} \times W \mathrm{WV}$ & 0.047 & $0.98-0.95$ & G, W & $8 \cdot 158$ & $0.02-0.01$ & G, V \\
\hline DV & $\mathrm{G} \times \mathrm{W}$ FS & $2 \cdot 317$ & $0.50-0.30$ & W & $24 \cdot 441$ & $<0.001$ & $\mathrm{~V}, \mathrm{~W}$ \\
\hline DV & G $\times W$ DV & 0.659 & $0.80-0.70$ & G, W & $19 \cdot 317$ & $<0.001$ & W \\
\hline FS & $\mathrm{W} \times \mathrm{G} F \mathrm{FS}$ & 0.528 & $0.80-0.70$ & G, W & 4.994 & $0 \cdot 10-0.05$ & $\mathrm{~V}, \mathrm{~W}$ \\
\hline & $\mathrm{W} \times \mathrm{G} \mathrm{DV}$ & $2 \cdot 873$ & $0 \cdot 30-0 \cdot 20$ & W & $3 \cdot 184$ & $0 \cdot 30-0 \cdot 20$ & G \\
\hline DV & $\mathrm{W} \times \mathrm{G}$ FS & $2 \cdot 841$ & $0 \cdot 30-0 \cdot 20$ & G, W & $5 \cdot 838$ & $0 \cdot 10-0 \cdot 05$ & G \\
\hline DV & $\mathrm{W} \times \mathrm{G} \mathrm{DV}$ & $2 \cdot 590$ & $0 \cdot 30-0 \cdot 20$ & G, W & 0.524 & $0.80-0.70$ & V \\
\hline
\end{tabular}

Even without these considerations in mind, it is clear from the $\chi^{2}$ analysis that there are no significant differences between the segregating ratios for total and good embryos.

The comparison between good embryos and seedlings shows no significant difference between the ratios for any of the $W \times G$ plastid crosses, and there is no consistent deficit for any one class. The comparison for $\mathrm{G} \times \mathrm{W}$ plastid crosses appears divided according to whether or not the green plastid parent was F. of Spring or D. Varden. In the former case there is probably no significant difference, although the FS $\mathrm{G} \times \mathrm{W}$ DV cross gave an extraordinary high proportion of white seedlings. It seems likely that this or the embryo ratios were atypical otherwise one would need to postulate selection against green embryos during development and germination. In the two $\mathrm{G} \times \mathrm{W}$ plastid crosses with $\mathrm{D}$. Varden as the source of chloroplasts there is a very significant decrease in the frequency of white seedlings compared with white embryos, indicating that in these crosses white embryos really are being selected against. Further support in favour of this selection is provided for the DV G $\times W$ DV plastid cross by the fact that the data given are the summation of repeated crosses made in summer 1965 in Köln and late autumn 1968 in Swansea; the two sets of data did not differ significantly $\left(\chi^{2}=3 \cdot 702\right.$, $\mathbf{P}=0 \cdot 2-0 \cdot 1)$, although selection appeared to be more severe in the 1965 series. The effect of this selection on the segregation ratios is not too profound, however, as the white embryos formed the smallest class from the outset.

\section{Fertilisation AND EMbryo SURVival}

The frequencies of from 1 to 10 total embryos per flower for the sixteen combinations of selfs and crosses within and between the two cultivars are 
TABLE 3

Frequencies of total and good embryos per flower for the sixteen combinations of selfs and crosses within and between the cultivars Flower of Spring and Dolly Varden

\begin{tabular}{|c|c|c|c|c|c|c|c|c|c|c|c|c|c|c|c|c|}
\hline \multirow{3}{*}{$\begin{array}{l}\text { Nos, of embryos } \\
\text { per Flower }\end{array}$} & \multicolumn{16}{|c|}{ Nos. of Flowers-Female parent Green } \\
\hline & \multicolumn{8}{|c|}{$\mathrm{G} \times \mathrm{G}$ Selfs and crosses } & \multicolumn{8}{|c|}{$G \times W$ Selfs and crosses } \\
\hline & $\mathrm{FS} \times$ & $x F$ & FS & DV & $D V \times$ & $x \mathrm{FSI}$ & & CDV & & & & DV & & & & $\times \mathrm{D}$ \\
\hline $10-7$ & - & - & - & - & - & - & - & - & - & - & - & - & - & - & - & - \\
\hline 10 & - & $\ldots$ & 1 & 1 & 5 & 5 & - & - & 2 & 1 & - & - & 9 & 7 & 1 & - \\
\hline 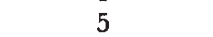 & 10 & 4 & 34 & 25 & 25 & 18 & 17 & 9 & 43 & 26 & 24 & 17 & 41 & 25 & 24 & 18 \\
\hline 4 & & 13 & 70 & 50 & 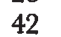 & 40 & 1 & 18 & 71 & & $\because$ & & & 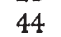 & & \\
\hline J & 2 & 33 & 57 & 59 & 33 & 36 & 29 & 25 & 66 & 61 & 56 & 53 & 35 & 43 & 36 & 30 \\
\hline 0 & 20 & 23 & 26 & 31 & 19 & 21 & 20 & 23 & 28 & 50 & 34 & 44 & 14 & 22 & 34 & 36 \\
\hline 1 & 6 & 10 & 11 & 15 & 19 & 21 & 15 & 18 & 10 & 18 & 21 & 25 & 7 & 11 & 25 & 16 \\
\hline 0 & - & - & - & 18 & - & 2 & - & 7 & - & 7 & - & - & - & 1 & - & 20 \\
\hline
\end{tabular}

$\begin{array}{lllllllllllllllll}\text { Total flowers } & 83 & 83 & 199 & 199 & 143 & 143 & 100 & 100 & 220 & 220 & 185 & 185 & 153 & 153 & 157 & 157\end{array}$

Nos. of Flowers-Female parent White

$\overbrace{\mathrm{FS} \times \mathrm{FS} F \mathrm{FS} \times \mathrm{DV} \text { DV } \times \mathrm{FS} \mathrm{DV} \times \mathrm{DV} \text { FS } \times \mathrm{FS} \mathrm{FS} \times \mathrm{DV} \mathrm{DV} \times \mathrm{FS} \mathrm{DV} \times \mathrm{DV}}^{\mathrm{W} \times \mathrm{W} \text { Selfs and crosses }}$

$\begin{array}{rrrrrrrrrrrrrrrrrrrr}10-8 & - & - & - & - & - & - & - & - & - & - & - & - & - & - & - & - \\ 7 & - & - & - & - & - & - & - & - & - & - & - & - & 1 & - & - & - \\ 6 & - & - & - & - & - & - & 3 & 2 & - & - & - & - & 8 & 3 & - & - \\ 5 & 22 & 14 & 20 & 12 & 22 & 11 & 18 & 8 & 10 & 6 & 9 & 5 & 19 & 4 & 2 & 1 \\ 4 & 36 & 31 & 30 & 28 & 65 & 39 & 37 & 25 & 21 & 9 & 20 & 16 & 35 & 19 & 18 & 6 \\ 3 & 35 & 34 & 41 & 41 & 65 & 65 & 39 & 38 & 30 & 16 & 19 & 14 & 31 & 22 & 35 & 9 \\ 2 & 16 & 22 & 28 & 31 & 52 & 54 & 23 & 26 & 21 & 20 & 21 & 14 & 13 & 28 & 55 & 30 \\ 1 & 15 & 21 & 28 & 35 & 16 & 35 & 13 & 25 & 9 & 14 & 16 & 20 & 10 & 11 & 38 & 29 \\ 0 & - & 2 & - & - & - & 16 & - & 9 & - & 26 & - & 16 & - & 30 & - & 73\end{array}$

$\begin{array}{llllllllllllllllll}\text { Total flowers } & 124 & 124 & 147 & 147 & 220 & 220 & 133 & 133 & 91 & 91 & 85 & 85 & 117 & 117 & 148 & 148\end{array}$

TABLE 4

Mean fertilisation of total and mean survival of good embryas and their respective standard errors for the sixteen combination of selfs and crosses

\begin{tabular}{|c|c|c|c|c|c|c|c|c|}
\hline & $\begin{array}{l}\text { Selfs and } \\
\text { crosses }\end{array}$ & $\begin{array}{c}\text { Nos. } \\
\text { flowers } \\
\text { pollinated }\end{array}$ & $\begin{array}{c}\text { Nos. } \\
\text { embryos } \\
\text { fertilised }\end{array}$ & $\begin{array}{l}\text { Mean } \\
\text { fertilisa- } \\
\text { tion }\end{array}$ & $\begin{array}{l}\text { Standard } \\
\text { error }\end{array}$ & $\begin{array}{c}\text { Nos. } \\
\text { embryos } \\
\text { surviving }\end{array}$ & $\begin{array}{c}\text { Mean } \\
\text { survival }\end{array}$ & $\begin{array}{l}\text { Standard } \\
\text { error }\end{array}$ \\
\hline $\begin{array}{l}\text { FS } \\
\text { FS } \\
\text { DV } \\
\text { DV }\end{array}$ & $\begin{array}{l}G \times G \quad F S \\
G \times G \quad D V \\
G \times G \quad F S \\
G \times G \quad D V\end{array}$ & $\begin{array}{r}83 \\
199 \\
143 \\
100\end{array}$ & $\begin{array}{l}255 \\
690 \\
479 \\
303\end{array}$ & $\begin{array}{l}3.072 \\
3.468 \\
3.350 \\
3.030\end{array}$ & $\begin{array}{l}0 \cdot 122 \\
0 \cdot 078 \\
0 \cdot 114 \\
0 \cdot 130\end{array}$ & $\begin{array}{l}227 \\
585 \\
451 \\
256\end{array}$ & $\begin{array}{l}2 \cdot 735 \\
2 \cdot 940 \\
3 \cdot 154 \\
2 \cdot 560\end{array}$ & $\begin{array}{l}0 \cdot 113 \\
0 \cdot 102 \\
0 \cdot 117 \\
0 \cdot 139\end{array}$ \\
\hline $\begin{array}{l}\text { FS } \\
\text { FS } \\
\text { DV } \\
\text { DV }\end{array}$ & $\begin{array}{l}\mathbf{G} \times W \text { FS } \\
\mathbf{G} \times W \mathrm{WV} \\
\mathbf{G} \times W \mathrm{FS} \\
\mathbf{G} \times W \mathrm{WV}\end{array}$ & $\begin{array}{l}220 \\
185 \\
153 \\
157\end{array}$ & $\begin{array}{l}775 \\
577 \\
587 \\
475\end{array}$ & $\begin{array}{l}3.523 \\
3.119 \\
3.837 \\
3.025\end{array}$ & $\begin{array}{l}0.075 \\
0.088 \\
0 \cdot 099 \\
0 \cdot 106\end{array}$ & $\begin{array}{l}665 \\
541 \\
527 \\
416\end{array}$ & $\begin{array}{l}3 \cdot 023 \\
2 \cdot 924 \\
3 \cdot 444 \\
2 \cdot 650\end{array}$ & $\begin{array}{l}0 \cdot 086 \\
0 \cdot 087 \\
0 \cdot 104 \\
0 \cdot 123\end{array}$ \\
\hline $\begin{array}{l}\text { FS } \\
\text { FS } \\
\text { DV } \\
\text { DV }\end{array}$ & $\begin{array}{l}\mathrm{W} \times \mathrm{G} \text { FS } \\
\mathrm{W} \times \mathrm{G} \mathrm{DV} \\
\mathrm{W} \times \mathrm{G} \text { FS } \\
\mathrm{W} \times \mathrm{G} \mathrm{DV}\end{array}$ & $\begin{array}{l}124 \\
147 \\
220 \\
133\end{array}$ & $\begin{array}{l}406 \\
427 \\
685 \\
432\end{array}$ & $\begin{array}{l}3 \cdot 274 \\
2 \cdot 905 \\
3 \cdot 114 \\
3 \cdot 248\end{array}$ & $\begin{array}{l}0 \cdot 112 \\
0 \cdot 108 \\
0 \cdot 074 \\
0 \cdot 107\end{array}$ & $\begin{array}{l}361 \\
392 \\
549 \\
343\end{array}$ & $\begin{array}{l}2 \cdot 911 \\
2 \cdot 667 \\
2 \cdot 495 \\
2 \cdot 579\end{array}$ & $\begin{array}{l}0 \cdot 117 \\
0 \cdot 104 \\
0 \cdot 087 \\
0 \cdot 121\end{array}$ \\
\hline $\begin{array}{l}\text { FS } \\
\text { FS } \\
\text { DV } \\
\text { DV }\end{array}$ & $\begin{array}{l}\mathrm{W} \times W \mathrm{FS} \\
\mathrm{W} \times \mathrm{W} \mathrm{DV} \\
\mathrm{W} \times \mathrm{W} \text { FS } \\
\mathrm{W} \times \mathbf{W} \mathrm{DV}\end{array}$ & $\begin{array}{r}91 \\
85 \\
117 \\
148\end{array}$ & $\begin{array}{l}275 \\
240 \\
419 \\
335\end{array}$ & $\begin{array}{l}3 \cdot 022 \\
2 \cdot 824 \\
3 \cdot 581 \\
2 \cdot 264\end{array}$ & $\begin{array}{l}0 \cdot 120 \\
0 \cdot 139 \\
0 \cdot 125 \\
0 \cdot 084\end{array}$ & $\begin{array}{l}168 \\
179 \\
247 \\
145\end{array}$ & $\begin{array}{l}1 \cdot 846 \\
2 \cdot 106 \\
2 \cdot 111 \\
0 \cdot 980\end{array}$ & $\begin{array}{l}0 \cdot 165 \\
0 \cdot 170 \\
0 \cdot 152 \\
0 \cdot 098\end{array}$ \\
\hline
\end{tabular}


given in table 3. Alongside are given the frequencies of from 0 to 10 good embryos. From these values, the calculated mean numbers of embryos per flower and their standard errors are given in table 4 . Since all means are based on a maximum of ten ovules per flower they may also be expressed as percentages of total ovules simply by moving the decimal place one digit to the right. The means from table 4 are converted to angles and the transformed data set out in table 5 together with row, column and overall totals

TABLE 5

Layout for the factorial analysis showing the angular transformed data from the mean fertilisation values of total and mean survival values of good embryos (table 4) for the sixteen combinations of selfs and crosses*

\begin{tabular}{cccccc} 
& \multicolumn{5}{c}{ Variety } \\
Plastids & FS $\times$ FS & FS $\times$ DV & DV $\times$ FS & DV $\times$ DV & Row totals \\
$\mathbf{G} \times \mathbf{G}$ & 33.66 & 36.08 & 35.37 & 33.40 & 138.51 \\
& 31.53 & 32.83 & 34.16 & 30.40 & 128.92 \\
$\mathbf{G} \times \mathrm{W}$ & 36.41 & 33.96 & 38.27 & 33.37 & 142.01 \\
& 33.36 & 32.73 & 35.93 & 30.98 & 133.00 \\
$\mathrm{~W} \times \mathrm{G}$ & 34.90 & 32.61 & 33.92 & 34.75 & 136.18 \\
& 32.66 & 31.09 & 29.96 & 30.52 & 124.23 \\
$\mathrm{~W} \times \mathrm{W}$ & 33.35 & 32.10 & 36.76 & 28.41 & 130.62 \\
& 25.44 & 27.32 & 27.36 & $(32.89)$ & $(135.10)$ \\
& & & & $(24.24$ & 98.36 \\
Column & 138.32 & 134.75 & 144.32 & 129.93 & $(104.44)$ \\
totals & & & & $(134.41)$ & 547.32 \\
& 122.99 & 123.97 & 127.41 & 110.14 & 484.51 \\
& & & & $(116.22)$ & $(490.59)$
\end{tabular}

* For each self or cross total embryos are placed above and surviving embryos below, estimated values or totals altered by estimates are placed in brackets.

and analysed as a $4 \times 4$ factorial (tables 6 and 7). Normality is assumed as each mean is the average of a large number of observations. There is no correlation between the means and their standard deviations.

The mean values for the selfed white $\mathrm{D}$. Varden (DV $\mathrm{W} \times \mathrm{W} \mathrm{DV}$ ) are significantly lower than for all other selfs and crosses taken as a group (table 8) and hence may be suspected of causing a bias to many of the comparisons to be analysed later. To alleviate this difficulty the analysis is also made with an estimated value for this self, and this value together with the altered row, column and overall totals is shown in the table too. The estimate of DV W $\times W \mathrm{DV}$ as a missing value is determined from the formula (Cochran and Cox, 1950):

$$
y=\frac{n R+n C-G}{(n-1)(n-1)}
$$

where $y$ is the estimate required

$R$ is the total of the remaining three values for $\mathrm{W} \times \mathrm{W}$

$C$ is the total of the remaining three values for $\mathrm{DV} \times \mathrm{DV}$

$G$ is the grand total of the fifteen known values

$n$ is the number of rows and columns (i.e. 4). 
The task of scoring over seven thousand embryos over a five-month period left no opportunity to replicate every self or cross. Consequently it is not possible to determine an error sum of squares in the usual way from the

TABLE 6

The analysis of variance for the angular transformed data of the mean fertilisation for total embryos (Table 5)

\begin{tabular}{|c|c|c|c|c|c|c|c|c|}
\hline \multirow[b]{2}{*}{ Source of Variance } & \multicolumn{4}{|c|}{ Aanalysis of Original Data } & \multicolumn{4}{|c|}{$\begin{array}{c}\text { Analysis with Estimate of } \\
\text { DV } W \times W D V\end{array}$} \\
\hline & S.S. & d.f. & $\chi^{2}$ & $\mathbf{P}$ & S.S. & d.f. & $\chi^{2}$ & $\mathbf{P}$ \\
\hline \multicolumn{9}{|l|}{ Variety: } \\
\hline FS $\times$ DV $ᄋ$ & 0.087 & 1 & 0.014 & $0.95-0.90$ & $2 \cdot 002$ & 1 & 0.318 & $0.70-0.50$ \\
\hline FS $\sigma^{+} \times \mathrm{DV} \sigma^{*}$ & $20 \cdot 160$ & 1 & $3 \cdot 224$ & $0 \cdot 10-0.05$ & $11 \cdot 357$ & 1 & $1 \cdot 803$ & $0 \cdot 20-0 \cdot 10$ \\
\hline Pure $\times$ Hybrid & $7 \cdot 317$ & 1 & $1 \cdot 170$ & $0 \cdot 30-0 \cdot 20$ & $2 \cdot 512$ & 1 & 0.399 & $0 \cdot 70-0 \cdot 50$ \\
\hline \multicolumn{9}{|l|}{ Plastids: } \\
\hline $\mathrm{G}$ \% $\times$ Wo & $11 \cdot 765$ & 1 & 1.881 & $0 \cdot 20-0 \cdot 10$ & $5 \cdot 336$ & 1 & 0.847 & $0.50-0.30$ \\
\hline $\mathrm{G} \partial \times \mathrm{W}^{+}$ & 0.265 & 1 & 0.042 & $0.90-0.80$ & $0 \cdot 366$ & 1 & 0.058 & $0.90-0.80$ \\
\hline Pure $\times$ Mixed & $5 \cdot 130$ & 1 & 0.820 & $0.50-0.30$ & $1 \cdot 311$ & 1 & $0 \cdot 208$ & $0.70-0.50$ \\
\hline Interactions & 31.914 & 9 & $5 \cdot 104$ & $0.90-0 \cdot 80$ & $20 \cdot 625$ & 9 & $3 \cdot 273$ & $0.98-0.95$ \\
\hline Total & 76.639 & 15 & - & - & $43 \cdot 509$ & 15 & - & - \\
\hline Theoretical error & $6 \cdot 253$ & - & - & - & $6 \cdot 300$ & - & - & - \\
\hline
\end{tabular}

TABLE 7

The analysis of variance for the angular transformed data of the mean survival for good embryos (table 5)

Analysis of Original Data

Source of Variance

Variety:

FS $\times$ DV 우

FS $\sigma^{2} \times$ DV $\sigma^{*} \quad 16 \cdot 58$

Pure $\times$ Hybrid

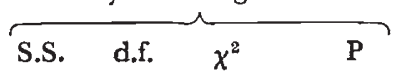

$\begin{array}{lll}5.534 & 1 & 0.885\end{array}$

$\begin{array}{lll}16.585 & 1 & 2 \cdot 652 \\ 20.816 & 1 & 3 \cdot 329\end{array}$

$20 \cdot 816$

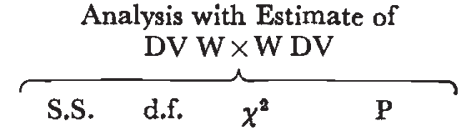

S.S.

$0 \cdot 50-0 \cdot 30$

$0 \cdot 20-0 \cdot 10$

$0 \cdot 10-0 \cdot 05$ $\begin{array}{llll}0.693 & 1 & 0 \cdot 110 & 0 \cdot 80-0 \cdot 70 \\ 6 \cdot 515 & 1 & 1 \cdot 034 & 0 \cdot 50-0 \cdot 30\end{array}$

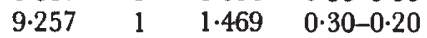

Plastids:

\begin{tabular}{|c|c|c|c|c|c|c|c|c|}
\hline $\mathrm{G} q \times \mathrm{W}$ 우 & 96.678 & 1 & $15 \cdot 460$ & $<0.001$ & $69 \cdot 098$ & 1 & $10 \cdot 967$ & $<0.001$ \\
\hline G ठ & $29 \cdot 6$ & 1 & $4 \cdot 746$ & $0 \cdot 05-0.02$ & $15 \cdot 425$ & 1 & $2 \cdot 448$ & $0 \cdot 20-0 \cdot 10$ \\
\hline Pure $\times$ Mixed & 56.063 & 1 & 8.965 & $0 \cdot 01-0.001$ & $35 \cdot 611$ & 1 & $5 \cdot 652$ & $0 \cdot 02-0.01$ \\
\hline Interactions & $37 \cdot 839$ & 9 & $6 \cdot 051$ & $0.80-0.70$ & $14 \cdot 819$ & 9 & $2 \cdot 352$ & $0.99-0.98$ \\
\hline 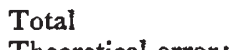 & $63 \cdot 191$ & 15 & 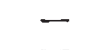 & - & $151 \cdot 418$ & 15 & - & - \\
\hline heo & $6 \cdot 253$ & 一 & - & - & $6 \cdot 300$ & & - & - \\
\hline
\end{tabular}

variance between replicates. Instead the theoretical error variance associated with the angular transformation analysis is used. This is determined by the formula (Fisher and Yates, 1963):

$$
\frac{820 \cdot 7}{n}
$$

where, for unequal samples, $n$ is the harmonic mean of the sample size. The theoretical error has an infinite number of degrees of freedom. Each sum of 
squares to be tested is divided by the theoretical error to give a $\chi^{2}$ value based on the number of degrees of freedom associated with the sum of squares in the numerator. The resulting $\chi^{2}$ are referred to the statistical table for judging significance.

The analysis of variance for the mean fertilisation of total embryos is summarised in table 6 together with the analysis using the estimated value for $\mathrm{DV} W \times \mathrm{W} D V$. The $\chi^{2}$ values show that there is no significant effect of variety or plastids or interactions at the 5 per cent. probability level. Hence it is reasonable to conclude that within and between the cultivars F. of Spring and D. Varden the percentage fertilisation achieved under greenhouse conditions does not vary with the parental combinations, either in respect of nuclear or plastid genotype. One exception to this rule, as already stated, is the selfed white $\mathrm{D}$. Varden. The 95 per cent. confidence limits for its mean fertilisation $(2 \cdot 098-2 \cdot 429)$ do not overlap with the confdence limits for any of the other fifteen means.

The analysis of variance for the mean survival of good embryos is summarised in table 7 together with the analysis using the estimated value for $\mathrm{DV} W \times \mathrm{W}$ DV. The $\chi^{2}$ values show that there is no significant effect of variety or interactions at the 5 per cent. level. By contrast, there is a highly significant effect for plastids. At the 0.1 per cent. probability level, the viability of embryos having a green plastid mother is significantly higher than for embryos having a white plastid mother. The interaction between embryos having pure versus mixed plastids is also significant at the 2 per cent. level, but this, as we shall see later (table 8), is caused by the particularly low values for all $W \times W$ plastid selfs. The colour of the plastids contributed by the male is just significant with the original data, but not after allowance is made for the particularly low value of $\mathrm{DV} W \times \mathrm{W} D$.

Armed with an estimate of the error variance, all contrasts between means can be evaluated (table 8) by the method of Scheffé (1959). The selfed white D. Varden, as already indicated, has a significantly lower mean fertilisation than the remaining fifteen means; the estimated value is not significantly different. In spite of the particularly low value for D. Varden, the four $\mathrm{W} \times \mathrm{W}$ means do not have a significantly lower mean fertilisation than the remaining twelve, nor is there any significant difference between the means of $\mathrm{G} \times \mathrm{G}, \mathrm{G} \times \mathrm{W}$ and $\mathrm{W} \times \mathrm{G}$ selfs and crosses.

When embryo survival is examined, quite a different picture emerges. It is not only the selfed white D. Varden that has a significantly lower mean, now all the four $\mathrm{W} \times \mathrm{W}$ plastid selfs are seen to have a much lower mean than the remaining twelve combinations, and this difference is significant at the $0 \cdot 1$ per cent. probability level; moreover the validity of this probability is confirmed by the use of the estimate analysis. Again there is no significant differences between the means for $G \times G, G \times W$ and $W \times G$ selfs and crosses. Hence the marked effect of green versus white female plastids (table 7) is due to the low viability of embryos from the $\mathrm{W} \times \mathrm{W}$ plastid selfs.

The fertility data for the seedlings (table 1) is limited to the mixed plastid crosses and is shown in table 9 . The number of embryos fertilised is based on the number of good, well-expanded seeds plus an estimate of those shrivelled seeds which are large enough to suggest that they have been fertilised and contain an embryo. The number of good seeds scored at ripening four to five weeks after pollination is also an estimate because the embryos within could not be inspected. Moreover, some seeds of doubtful quality were 


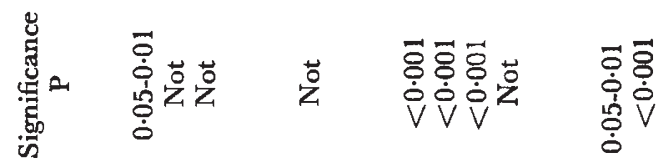
1
1

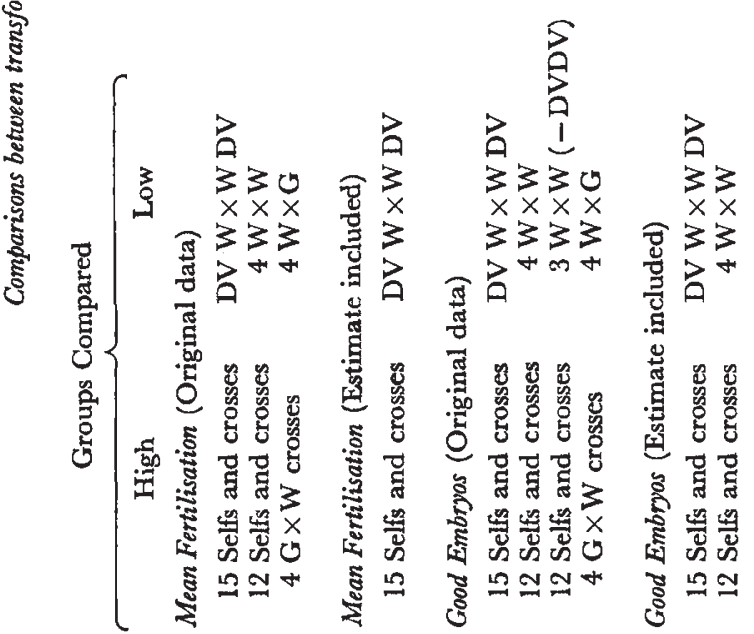


scored as good, and were duly sown to test their ability to germinate. As expected, for all crosses, the mean germination per flower is less than the mean survival of good embryos up to three weeks old (table 4), indicating that embryo breakdown continues during the ripening period and subsequent germination. What was less expected, is the apparent discrepancy between

TAble 9

The mean fertilisation, good seeds, and germination per fower for the eight mixed plastid crosses

\begin{tabular}{|c|c|c|c|c|c|c|c|}
\hline $\begin{array}{c}\text { Selfs and } \\
\text { crosses }\end{array}$ & $\begin{array}{c}\text { Nos. } \\
\text { flowers } \\
\text { pollinated }\end{array}$ & $\begin{array}{c}\text { Estimate } \\
\text { nos. embryos } \\
\text { fertilised }\end{array}$ & $\begin{array}{l}\text { Mean } \\
\text { fertilisa- } \\
\text { tion }\end{array}$ & $\begin{array}{c}\text { Estimate } \\
\text { nos. good } \\
\text { seeds }\end{array}$ & $\begin{array}{c}\text { Mean } \\
\text { good } \\
\text { seeds }\end{array}$ & $\begin{array}{c}\text { Nos. } \\
\text { germinated } \\
\text { seedlings }\end{array}$ & $\begin{array}{l}\text { Mean } \\
\text { germina- } \\
\text { tion }\end{array}$ \\
\hline FS $\quad G \times W F S$ & 114 & - & - & 226 & 1.982 & 191 & 1.675 \\
\hline FS $\quad G \times W D V$ & 74 & 234 & $3 \cdot 162$ & 180 & $2 \cdot 432$ & 152 & $2 \cdot 054$ \\
\hline DV $G \times W F S$ & 151 & 575 & 3.808 & 495 & $3 \cdot 278$ & 462 & 3.060 \\
\hline $\mathrm{DV} G \times \mathrm{W} D V$ & 134 & $(253$ & $3 \cdot 163)^{*}$ & 310 & $2 \cdot 313$ & 235 & $1 \cdot 754$ \\
\hline FS $\quad W \times G \quad F S$ & 80 & 一 & - & 152 & 1.900 & 144 & $1 \cdot 800$ \\
\hline $\mathrm{FS} \quad \mathrm{W} \times \mathrm{G} D \mathrm{DV}$ & 80 & 264 & $3 \cdot 300$ & 204 & $2 \cdot 550$ & 175 & $2 \cdot 188$ \\
\hline $\mathrm{DV} W \times \mathrm{G} F \mathrm{~S}$ & 111 & 417 & $3 \cdot 757$ & 321 & $2 \cdot 892$ & 257 & $2 \cdot 315$ \\
\hline $\mathrm{DV} W \times \mathrm{G} D V$ & 107 & $(209$ & $2.944) \uparrow$ & 207 & 1.935 & 161 & $1 \cdot 505$ \\
\hline
\end{tabular}

* Fertilisation data based on 80 flowers only.

+ Fertilisation data based on 71 flowers only.

the lower mean germination of the four F. of Spring and D. Varden nuclear selfs compared with the higher means for the four F. of Spring $\times D$. Varden hybrids. It will be remembered that the analysis of variance test showed no significant difference between pure and hybrid crosses for the survival of three-week-old embryos (table 7 ). The means for mature and germinating

TABLe 10

Layout for the factorial analysis showing the angular transformed data from the mean values of good and germinating seeds (table 9) for the eight mixed plastid crosses*

\begin{tabular}{|c|c|c|c|c|c|}
\hline & & & Variety & & \\
\hline Plastids & $\mathrm{FS} \times \mathrm{FS}$ & $\mathrm{FS} \times \mathrm{DV}$ & $\mathrm{DV} \times \mathrm{FS}$ & $\mathrm{DV} \times \mathrm{DV}$ & Row totals \\
\hline $\mathrm{G} \times \mathrm{W}$ & $\begin{array}{l}26 \cdot 43 \\
24 \cdot 16\end{array}$ & $\begin{array}{l}29 \cdot 54 \\
26 \cdot 95\end{array}$ & $\begin{array}{l}34.93 \\
33 \cdot 58\end{array}$ & $\begin{array}{l}28 \cdot 75 \\
24 \cdot 76\end{array}$ & $\begin{array}{l}119 \cdot 65 \\
109 \cdot 45\end{array}$ \\
\hline $\mathrm{W} \times \mathrm{G}$ & $\begin{array}{l}25 \cdot 84 \\
25 \cdot 10\end{array}$ & $\begin{array}{l}30 \cdot 33 \\
27 \cdot 89\end{array}$ & $\begin{array}{l}32 \cdot 53 \\
28 \cdot 76\end{array}$ & $\begin{array}{l}26 \cdot 10 \\
22 \cdot 83\end{array}$ & $\begin{array}{l}114 \cdot 80 \\
104 \cdot 58\end{array}$ \\
\hline $\begin{array}{c}\text { Column } \\
\text { totals }\end{array}$ & $\begin{array}{l}52 \cdot 27 \\
49 \cdot 26\end{array}$ & $\begin{array}{l}59 \cdot 87 \\
54 \cdot 84\end{array}$ & $\begin{array}{l}67 \cdot 46 \\
62 \cdot 34\end{array}$ & $\begin{array}{l}54 \cdot 85 \\
47 \cdot 59\end{array}$ & $\begin{array}{l}234 \cdot 45 \\
214 \cdot 03\end{array}$ \\
\hline
\end{tabular}

* For each self or cross good seeds are placed above and germinating seedlings below.

seeds from table 9 are converted to angles, and the transformed data set out in table 10, together with row, column and overall totals, and analysed as a $4 \times 2$ factorial. The $\chi^{2}$ values for the analysis (table 11 ) confirm that the frequency of surviving hybrids is indeed significantly greater than the selfs at the 2 per cent. level; this is true equally for the mature seeds and the germinating seedlings. It is not clear why this differentiation between selfs 
and hybrids is not apparent until seed maturity. It may be a lethal factor operating in embryos during the ripening process. Or it may be that the breakdown, which begins before three weeks, is only expressed in the cold, short-day climate of November and December and not in the warmer and longer days of May till October when the three-week-old embryos were examined. A further clarification of these germination differences must await a comparison of the green and white plastid selfs.

\section{TABLE 11}

The analysis of variance for the angular transformed data of the mean survival for mature seeds and germinating seedlings (table 10)

\begin{tabular}{|c|c|c|c|c|c|c|c|c|}
\hline \multirow[b]{2}{*}{ Source of variance } & \multicolumn{4}{|c|}{ Mature Seeds } & \multicolumn{4}{|c|}{ Germinating Seedlings } \\
\hline & S.S. & d.f. & $\chi^{2}$ & $\mathbf{P}$ & S.S. & d.f. & $\chi^{2}$ & $\mathbf{P}$ \\
\hline \multicolumn{9}{|l|}{ Variety: } \\
\hline FS $\times$ DV 우 & $12 \cdot 929$ & 1 & 1.581 & $0 \cdot 30-0.20$ & $4 \cdot 249$ & 1 & 0.519 & $0.50-0.30$ \\
\hline FS $\bar{\sigma} \times \mathrm{DV} \sigma$ & $3 \cdot 138$ & 1 & 0.384 & $0.70-0.50$ & $10 \cdot 511$ & 1 & $1 \cdot 285$ & $0.30-0.20$ \\
\hline Pure $\times$ Hybrid & $51 \cdot 056$ & 1 & $6 \cdot 242$ & $0 \cdot 02-0.01$ & $51 \cdot 664$ & 1 & $6 \cdot 317$ & $0.02-0.01$ \\
\hline \multicolumn{9}{|l|}{ Plastids: } \\
\hline 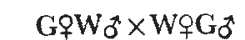 & $2 \cdot 940$ & 1 & $0 \cdot 360$ & $0.70-0.50$ & 2.965 & 1 & 0.362 & $0.70-0.50$ \\
\hline Interactions & $3 \cdot 937$ & 3 & $0 \cdot 481$ & $0.95-0.90$ & $11 \cdot 398$ & 3 & $1 \cdot 394$ & $0 \cdot 80-0 \cdot 7$ \\
\hline Total & $74 \cdot 000$ & 7 & $\longrightarrow$ & - & $80 \cdot 786$ & 7 & - & - \\
\hline Theoretical error: & $8 \cdot 179$ & - & - & - & $8 \cdot 179$ & $一$ & - & - \\
\hline
\end{tabular}

\section{Discussion}

The question of whether the observed ratios of green, variegated and white embryos, obtained after mixed plastid crosses, are in any way the products of selection against white embryos during the course of development may now be considered. Following such crosses within F. of Spring or within D. Varden, it was observed that the segregation ratios of green, variegated and white seedlings were not markedly different from those of young embryos (Tilney-Bassett, 1965). For the most part, the results of the present paper confirm this principle and extend it to include crosses between the two cultivars. Moreover, the results show that the segregation ratios do not differ as between total embryos and good embryos, and as between good embryos and seedlings (table 2). Exceptional are the significant numbers of white embryos that appear to be preferentially eliminated between three weeks and germination in the two $\mathrm{G} \times \mathrm{W}$ plastid crosses with $\mathrm{D}$. Varden as female parent. These two exceptions may be regarded as examples of weak selection in the sense that there is no profound change in the pattern of segregation because the white embryos were fewer than green or variegated from the outset (table 1). In no case is there any evidence for selection against any white embryos between fertilisation and three-week-old embryos. Any major modification of the varying segregation patterns by selection against embryos big enough to see and score is thus ruled out. Hence we must once again inquire whether there is any possibility of selection occurring during the first few days after fertilisation when dead embryos would be too small to see with the stereomicroscope.

If there is any significant selection against white embryos during the very early stages of development, such that they escape scoring at three 
weeks, then their absence should be detectable by a lowering of the mean fertilisation value as compared with other selfs and crosses. Thus a strong selection against white embryos at this early period would account for the fact that in all $\mathrm{W} \times \mathrm{G}$ plastid crosses the majority of the embryos are green after the male parent, instead of the expected white after the female parent; in other words selection would conveniently explain the predominantly paternal inheritance. The analysis of the fertilisation data shows that there is no significant difference between the mean fertilisation of any of the sixteen combinations, except the selfed white $\mathrm{D}$. Varden unimportant in this context. Consequently there are no grounds at all for assuming selection against very young white embryos in $\mathrm{W} \times \mathrm{G}$ or $\mathrm{G} \times \mathrm{W}$ plastid crosses. The selection hypothesis must therefore be rejected. The objection that the present method of analysis does not take account of the possibility that some embryos may be eliminated very early in development of all selfs and crosses has been considered by microscopic examination of serial sections within the two cultivars (Tilney-Bassett, 1965). Of the two $\mathrm{G} \times \mathrm{W}$ plastid crosses, the microscopic estimation of total fertilisation is higher for $F$. of Spring and lower for D. Varden compared with the present method (table 4), whereas in the two $\mathrm{W} \times \mathrm{G}$ plastid crosses, the order is reversed. Moreover, the highest fertilisation value for the serial sections is only slightly higher than the highest present value. These observations indicate that even if a few embryos are overlooked, and even if these are only white ones, they are far too few to seriously affect the pattern of segregation.

Rejection of the selection hypothesis has two advantages. Firstly, in order to account for the extreme deficit of white embryos in the two $\mathrm{W} \times \mathrm{G}$ plastid crosses with F. of Spring as the source of white plastids (table l) the lowering of the mean fertilisation values would have had to be very considerable, and there was never any strong indication that this was the case. A second and more important consideration is that the hypothesis of strong selection against white embryos in $W \times G$ plastid crosses always appeared incompatible with the extraordinary high frequency of white embryos, containing the same white plastids, in the two $\mathrm{G} \times \mathrm{W}$ plastid crosses with $\mathrm{F}$. of Spring as female parent.

In the absence of selection, alternative explanations to account for the varying plastid behaviour must be sought. A number of the possibilities open to consideration have been discussed elsewhere (Kirk and TilneyBassett, 1967), but since there is no pressing reason for emphasising any particular one of them I do not propose to discuss them further here. It is worth noting, however, that the possibility of a considerable number of plastids entering from the male parent has recently been strengthened by results from a study of the ultrastructure of the male generative cell. Lombardo and Gerola (1968) find that " proplastids are so numerous in the male generative cell that it is quite conceivable that some of them pass into the egg cell wall together with the male nucleus, although the egg cell wall remains open only for a short time". The classical example of purely maternal inheritance of plastids, always quoted though never rigorously proven, is Mirabilis jalapa (see Kirk and Tilney-Bassett, 1967). In this plant Lombardo and Gerola have found proplastids to be scanty or totally absent from the male generative cell. Clearly the presence or absence of proplastids in this cell is likely to be at least one of the deciding factors leading to or preventing the transmission of plastids by the male. 
Although there is little or no preferential elimination of white embryos there is quite a strong selection against embryos in general many of which never survive to maturity. The limited data available (table 9) show that the selfs are less viable than the hybrids suggesting that at least a part of the fertility losses are due to the segregation of homozygous lethals. The fertility losses of $\mathrm{W} \times \mathrm{W}$ selfs and crosses at three weeks is significantly worse than for all other plastid combinations (table 8), and earlier data on the selfs (TilneyBassett, 1963b) shows that this trend continues through to germination which is very poor. It would appear to be the particular combination of white plastids from both parents that leads to early and extensive embryo breakdown. The $\mathrm{W} \times \mathrm{G}$ plastid crosses produce a few white embryos, but there is no suggestion that these are anything like as inviable as the white embryos from $W \times W$ plastid selfs, and the numerous white embryos produced by some $\mathrm{G} \times \mathrm{W}$ plastid crosses, but not all, are able to survive just as well as the green ones. It is difficult to see why white embryos should vary so much in their viability, but two factors may have some bearing on the problem. Firstly, white embryos from $\mathrm{W} \times \mathrm{G}$ plastid crosses often have green chloroplasts at the suspensor end of the embryo at the tip of the growing radicle which white embryos from white plastid selfs naturally do not have. Curiously and perhaps significantly these green-tipped suspensors are virtually absent from the numerous white embryos produced by the $G \times W$ plastid crosses with F. of Spring as the female parent, but are quite common when D. Varden is the female parent. Secondly, white embryos from $G \times W$ plastid crosses presumably have predominantly normal plastids in their endosperm, whereas the endosperm of embryos from white plastid selfs would contain only mutant plastids, and this too might be important. It would be interesting to know more about the function of normal plastids in the endosperm of Pelargonium; they do not develop into chloroplasts, but might have a nutritional function that the mutant plastids are unable to carry out efficiently, or mutant plastids might have an adverse effect on cell division. It seems likely that many of the problems associated with the breeding results will not be satisfactorily resolved until more information is available on the behaviour of the plastids themselves at fertilisation and during early embryo and endosperm development.

\section{SUMMARY}

1. Clones of Pelargonium zonale cultivars Flower of Spring and Dolly Varden, containing either normal green or mutant white plastids in their germ layers, are selfed and crossed in all sixteen of the possible combinations.

2. Comparison of segregation ratios (table 1) for the eight mixed plastid crosses show no significant change between total embryos and healthy threeweek-old embryos. Between three-week-old embryos and germination, there is a highly significant selection against white embryos only for the two $G \times W$ crosses with D. Varden as the source of green plastids (table 2). Since white embryos form the smallest class from the outset, the effect of this selection on their segregation ratios is fairly mild.

3. By analysis of variance the effects of the cultivars are distinguished from the effects of the plastids, at fertilisation, and at three stages of embryo development.

4. Variations in the cultivar parentage have no significant effect on 
mean fertilisation (table 6), or mean survival of three-week-old embryos (table 7). There is evidence for a reduced viability of inbred compared with hybrid seed at maturity and germination (table 11).

5. Variations in the plastid parentage have no significant effect on mean fertilisation (table 6), but an effect on mean survival of three-week-old embryos (table 7) is due to the particularly low viability of white embryos produced by $\mathrm{W} \times \mathrm{W}$ selfs and crosses (table 8 ).

6. The combination, in all $\mathrm{G} \times \mathrm{W}$ and $\mathrm{W} \times \mathrm{G}$ crosses, of no difference in mean fertilisation, no difference in embryo survival between fertilisation and three weeks after, and no change in the proportion of green, variegated and white embryos, demonstrates that there is no preferential elimination of white embryos in the earliest days of development.

7. The absence of early selection against white embryos greatly strengthens the evidence for a predominantly paternal inheritance of plastids in all $\mathrm{W} \times \mathrm{G}$ plastid crosses. Among $\mathrm{G} \times \mathrm{W}$ crosses, plastid inheritance is predominantly maternal when $\mathrm{D}$. Varden is the source of green plastids, but approaches equality with F. of Spring as the source of green plastids.

Acknowledgments.-I wish to thank Dr Thomas C. Long for discussions of the statistical analysis and Miss Susan Leonard for her technical assistance.

\section{REFERENCES}

BAUR, E. 1909. Das Wesen und die Erblichkeitsverhältnisse der "Varietates albomarginatae hort" von Pelargonium zonale. Z. VererbLehre, 1, 330-351.

cochran, w. G., AND cox, G. M. 1950. Experimental Designs. John Wiley and Sons Inc., New York and London.

FIsher, R. A., AND YATEs, F. 1963. Statistical Tables for Biological, Agricultural and Medical Research, 6th ed. Oliver and Boyd, Edinburgh and London.

hagemann, R. 1964. Plasmatische Vererbung. Genetik Grundlagen, Ergebnisse und Probleme in Einzeldarstellungen. Veb Gustav Fisher Verlag, Jena.

KIRK, J. T. O., AND TILNEY-BAssETt, R. A. E. 1967. The Plastids: Their Chemistry, Structure, Growth and Inheritance. W. H. Freeman and Company, London and San Francisco.

LOMBARDO, G., AND GEROLA, F. M. 1968. Cytoplasmic inheritance and ultrastructure of the male generative cell of higher plants. Planta, 82, 105-110.

scheFfé, H. 1959. The Analysis of Variance. John Wiley and Sons Inc., New York and London.

schöтZ, F. 1954. Ưber Plastidenkonkurrenz bei Oenothera. Planta, 43, 182-240.

scнӧтz, F. 1958. Beobachtungen zur Plastidenkonkurrenz bei Oenothera und Beiträge zum Problem der Plastidenvererbung. Planta, 51, 173-185.

schötz, F. 1958. Ủber Plastidenkonkurrenz bei Oenothera II. Biol. Zbl., 87, 33-61.

TILNEY-BASSETT, R. A. E. 1963a. The structure of periclinal chimeras. Heredity, 18, 265-285.

TILNEY-BASSETT, R. A. E. 1963b. Genetics and plastid physiology in Pelargonium. Heredity, 18, 485-504.

TILNEY-Bassett, R. A. E. 1965. Genetics and plastid physiology in Pelargonium I1. Heredity, $20,451-466$. 